\title{
Chitinase-Induced Airway Hyperreactivity and Inflammation in a Mouse Model of Nonallergic Asthma
}

\author{
Christina Weber-Chrysochoou $^{\text {a }}$ Yasemin Darcan-Nicolaisen $^{b}$ \\ Johanna Wohlgensinger ${ }^{c, d}$ Eva Maria Tinner ${ }^{e, f}$ Remo Frei ${ }^{d, g}$ Susanne Loeliger ${ }^{c, d}$ \\ Roger P. Lauener ${ }^{d, h}$ Eckard Hamelmann ${ }^{b, i}$ \\ ${ }^{a}$ Allergy Unit, Dermatology Department, University Hospital of Zurich, Zurich, Switzerland; ${ }^{b}$ Department of Pediatric \\ Pneumology and Immunology, University Hospital Charité, Berlin, Germany; 'University Children's Hospital Zurich, \\ Zurich, Switzerland; 'Christine Kühne-Center for Allergy Research and Education (CK-CARE), Davos, Switzerland; \\ eDivision of Pediatric Hematology/Oncology, University Children's Hospital of Bern, Inselspital, Bern, Switzerland; \\ fDepartment of Medicine, Kantonsspital Baselland, Liestal, Switzerland; 9Division of Respiratory Medicine, Department \\ of Pediatrics, University of Bern Inselspital, Bern, Switzerland; hChildren's Hospital St Gallen, St Gallen, Switzerland; \\ 'Department of Pediatrics, Evangelisches Klinikum Bethel EvKB, University Bielefeld, Bielefeld, Germany
}

\section{Keywords}

Airway inflammation $\cdot$ Chitinase $\cdot$ Fungi $\cdot$ Mites $\cdot$ Innate immune system

\begin{abstract}
Introduction: Environmental exposure to mites and fungi has been proposed to critically contribute to the development of IgE-mediated asthma. A common denominator of such organisms is chitin. Human chitinases have been reported to be upregulated by interleukin-13 secreted in the context of Th2-type immune responses and to induce asthma. We assessed whether chitin-containing components induced chitinases in an innate immune-dependent way and whether this results in bronchial hyperresponsiveness. Materials and Methods: Monocyte/macrophage cell lines were stimulated with chitin-containing or bacterial components in vitro. Chitinase activity in the supernatant and the expression of the chitotriosidase gene were measured by enzyme assay and quantitative PCR, respectively. Non-sensitized mice were stimulated with chitin-containing components
\end{abstract}

karger@karger.com www.karger.com/iaa

Karger $\stackrel{\text { ' }}{5}$

GOPEN ACCESS
(C) 2021 The Author(s)

Published by S. Karger AG, Basel

This is an Open Access article licensed under the Creative Commons Attribution-NonCommercial-4.0 International License (CC BY-NC) (http://www.karger.com/Services/OpenAccessLicense), applicable to the online version of the article only. Usage and distribution for commercial purposes requires written permission. intranasally, and a chitinase inhibitor was administered intraperitoneally. As markers for inflammation leukocytes were counted in the bronchoalveolar lavage (BAL) fluid, and airway hyperresponsiveness was assessed via methacholine challenge. Results: We found both whole chitin-containing dust mites as well as the fungal cell wall component zymosan A but not endotoxin-induced chitinase activity and chitotriosidase gene expression in vitro. The intranasal application of zymosan A into mice led to the induction of chitinase activity in the BAL fluid and to bronchial hyperresponsiveness, which could be reduced by applying the chitinase inhibitor allosamidin. Discussion: We propose that environmental exposure to mites and fungi leads to the induction of chitinase, which in turn favors the development of bronchial hyperreactivity in an IgE-independent manner.

(C) 2021 The Author(s)

Published by S. Karger AG, Basel

R.L. and E.H. jointly supervised this project and contributed equally to this manuscript.

Edited by: H.-U. Simon, Bern. 


\section{Introduction}

Asthma is one of the most common chronic diseases in children and adolescents [1] and is characterized by reversible airway obstruction, inflammation, and airway hyperreactivity. The majority of asthma patients in this age-group show signs of the so-called T2 type of asthma: a phenotype that is characterized by the enhanced production of T-helper cell type 2 cytokines, interleukin (IL)4, IL-5, and IL-13 and elevated concentrations of serum IgE as hallmarks of allergic asthma [2]. In this line, major risk factors for asthma in children are the general presence of atopy in the family or the child [3] and, more specifically, their early sensitization to house dust mites (HDMs) $[4,5]$. Particularly in atopic asthmatics, there is a clear association with the indoor climatic quality as a marker for exposure to indoor allergens, environmental tobacco smoke, and disease [6].

However, this link seems not to be solemnly dependent on IgE or allergic sensitization since a relationship between exposure to domestic allergens and bronchial hyperresponsiveness has also been described in adult atopic asthma patients who were only sensitized to allergens other than HDMs or other indoor allergens [7]. Supportive of this, atopic children (sensitized to indoor and/ or outdoor allergens, but not to fungi) exposed to high concentrations of molds in school and children living in desert environments with little or no mite allergen exposure suffered from asthma symptoms or asthma worsening after exposure to fungi, which was most likely caused by a direct, non-IgE-mediated interaction $[8,9]$. This may also explain why in the MAS study, a multicentre birth cohort exploring the natural development of allergies and asthma, no correlation between HDM levels and atopy or childhood asthma was found [4]. This also suggests that a different pathway besides IgE-mediated allergic sensitization may play a role in asthma development.

A possible candidate for this second pathway is chitin. Chitin is a common carbohydrate found in mites and fungi, but not in mammalians. Chitin particles are recognized by the immune system via receptors of the innate immunity [10] and thus induce the expression of chitinases as effector molecules for defense in plants, fish, and insects. An antiparasitic role of human chitinases has not yet been described [11], but a role that chitinases may play in asthma seems likely. Acidic mammalian chitinase (AMCase), an endogenous lung chitinase induced by IL13 , has been reported as a pivotal factor in the pathogenesis of (experimental) allergic asthma, whereas inhibition of AMCase activity suppressed this inflammatory process
$[12,13]$. In humans, 2 chitinases with chitin-cleaving activity have been described: AMCase and chitotriosidase. AMCase activity was found to be elevated in the lung tissues of asthmatic patients, and the expression of specific AMCase polymorphisms was associated with bronchial asthma in children [14]. Further, increased serum chitotriosidase activity was observed in children and adults with asthma [15]. The chitinase-like protein YKL-40, which lacks chitin-cleavage activity, has been found elevated in the plasma of asthma patients at levels correlating with the lung function $[16,17]$. To further examine the role of chitinase in the development of asthma, we investigated whether mammalian chitinase can be induced via the stimulation of TLRs, the principal pattern recognition receptors of the innate immune system, and whether this chitinase induction will enhance inflammation and bronchial hyperreactivity independent of IgE.

\section{Materials and Methods}

\section{Cell Lines}

Human monocyte cell line (THP-1) and mouse monocyte and macrophage cell line (RAW 264.7) were purchased from the European Collection of Cell Cultures (ECACC) in the UK and grown in RPMI 1640 or DMEM (Gibco BRL) supplemented with $10 \%$ low-endotoxin FBS (Hyclone) and $1 \%$ of an antibiotic-antimycotic solution (Gibco BRL). Human monocyte-macrophages were isolated from the fresh buffy coats of healthy volunteers using a Ficoll-Paque gradient (Amersham Biosciences AB, Uppsala, Sweden) and grown in RPMI 1640 supplemented with 10\% low-endotoxin FBS and $1 \%$ of an antibiotic-antimycotic solution.

\section{Cell Stimulation and Total RNA Extraction}

Cells grew in 6-well plates at $37^{\circ} \mathrm{C}$ with $5 \% \mathrm{CO}_{2}$ until they were $80 \%$ confluent. The cells were stimulated in a serum-free medium for $6 \mathrm{~h}$ with LPS $100 \mathrm{ng} / \mathrm{mL}$ (Escherichia coli K12, List Biological Laboratories, Campbell, CA, USA), zymosan A (Saccharomyces cerevisiae) $250 \mu \mathrm{g} / \mathrm{mL}$ (Molecular Probes, Eugene, OR, USA) or Dermatophagoides pteronissinus (Der. p.) $100 \mu \mathrm{g} / \mathrm{mL}$ (Allergon $\mathrm{AB}$, Aengelholm, Sweden). To investigate the receptor pathway, we added $2 \mu \mathrm{g} / \mathrm{mL}$ monoclonal antibodies against dectin-1 (R\&D, UK), anti-TLR-2 (eBioscience, USA), or anti-CD 205 (mannose receptor) (BD Bioscience, Switzerland). The supernatant was taken and immediately frozen at $-20^{\circ} \mathrm{C}$. The QIAmp RNA Blood Mini Kit (Qiagen) supplemented with RNase-free DNase (Qiagen) was used for a total RNA isolation.

\section{RT-PCR and Quantitative PCR (TaqMan $\left.{ }^{\circledR}\right)$ of In Vitro Material}

We performed reverse transcription with $300 \mathrm{ng}$ of total RNA in a final volume of $30 \mu \mathrm{L}$ using the reverse transcription reagents of Applied Biosystems (Forster City, CA, USA). The quantitative real-time PCR was carried out in an ABI Prism 7700 Sequence Detection System ${ }^{\mathrm{TM}}$ (Applied Biosystems). To detect the gene for $18 \mathrm{~S}$ rRNA, we used the primers with the sequence $5^{\prime}$-AGTCCCT- 
GCCCTTTGTACACA-3' (200 mM) and 5'-GATCCGAGGGCCTCACTAAAC- $3^{\prime}(200 \mathrm{mM})$. The probe had the sequence 5'-CGCCCGTCGCTACTACCGATTGG-3' (250 mM). To measure the expression of the human chitotriosidase gene (Hs 00185753_m1), of the human AMCase gene (Hs 00757767_m1) and of the mouse chitotriosidase gene (Mm 01291362_ml), we used pre-developed assays (Applied Biosystems). The quantitative real-time PCR was performed with $3 \mu \mathrm{L}$ of the reverse transcription solution in a final volume of $25 \mu \mathrm{L}$. We added an adequate amount of primers and probes, together with $12.5 \mu \mathrm{L}$ TaqMan Universal PCR Master Mix ${ }^{\mathrm{TM}}$ (Applied Biosystems). We normalized the determined gene expression values to the parallel measured endogenous control $18 \mathrm{~S}$ rRNA and analyzed the data with the comparative $(\Delta \Delta C t)$ method according to the manufacturer's instructions (Applied Biosystems).

\section{Animals}

Female BALB/c mice, 6-8 weeks old, were purchased from the Harlan-Winkelmann GmbH, Borchen, Germany. The animals were certified as pathogen and virus-free according to the supplier: the mice were kept under pathogen-free conditions and maintained a standard diet and water ad libitum. The animal Ethics Committee (Ethik Kommission der Charité Universitätsmedizin Berlin) approved all experimental procedures.

The mice were anesthetized with isoflurane and intranasally challenged daily with $100 \mu \mathrm{g}(4 \mathrm{mg} / \mathrm{mL})$ zymosan A in PBS or 25 $\mu \mathrm{L}$ PBS for 5 days. Four hours before the intranasal challenge, the mice had an intraperitoneal application of $30 \mu \mathrm{g}$ of the chitinase inhibitor allosamidin (Industrial Research, New Zealand) or PBS.

On day $5,24 \mathrm{~h}$ after the last intranasal stimulation, in vivo lung function to inhaled methacholine (MCh; Sigma, St Louis, MO, USA) was measured by whole-body plethysmography (WBP; EMKA Technologies, Paris, France), as previously reported [18]. Each mouse was placed briefly in the main chamber of a body plethysmograph. Aerosolized PBS (baseline) and MCh in increasing concentrations $(6-50 \mathrm{mg} / \mathrm{mL})$ were nebulized ultrasonically through an inlet of the main chamber for $3 \mathrm{~min}$. Pressure differences between the main and the reference chamber caused by volume and resultant pressure changes during the mouse's inspiration and expiration were measured and averaged for 3 min after each nebulization. Enhanced pause (Penh) values were calculated as an index of airway obstruction.

On day 5, mice were assessed for airway inflammation. Lungs were lavaged twice via a tracheal tube with $0.8 \mathrm{~mL}$ of cold PBS (Seromed, Biochrom, Berlin, Germany) supplemented with protease inhibitor cocktail tablets (Cat. No. 11836153 001, complete mini, Roche, Penzberg, Germany). Cells were counted, and cytospin slides were stained with Diff Quick (Dade Behring AG, Düdingen, Switzerland). Bronchoalveolar lavage (BAL) cells were differentiated according to morphological criteria by counting at least 100 cells using standard hematological procedures under light microscopy. The cell-free BAL fluid of the first lavage was stored at $-70^{\circ} \mathrm{C}$ until the cytokine assay.

Enzyme Assays in vivo and in vitro

Chitinase enzyme activity was determined with fluorogenic substrate 4-methylumbelliferyl- $\beta-\mathrm{D}-\mathrm{N}, \mathrm{N}^{\prime}, \mathrm{N}^{\prime \prime}$-triacetylchitotrioside (Sigma M-5639) as previously described [19]. Then $50 \mu \mathrm{L}$ of undiluted supernatant was incubated with $100 \mu \mathrm{L}$ of a solution containing $22 \mu \mathrm{mol} /$ Loftheartificialsubstrate4-methylumbelliferyl-

Chitinase-Induced Nonallergic Asthma in Mice
$\beta-\mathrm{D}-\mathrm{N}, \mathrm{N}^{\prime}, \mathrm{N}^{\prime \prime}$-triacetylchitotrioside (Sigma M-5639) in a $0.5 \mathrm{~mol} / \mathrm{L}$ citrate phosphate buffer with a $\mathrm{pH}$ of 5.2 for $15 \mathrm{~min}$ at $37^{\circ} \mathrm{C}$. The reaction was stopped by using $3 \mathrm{~mL}$ of $\mathrm{Na}_{2} \mathrm{CO}_{3} 100 \mathrm{mM}$ and 10.6 $\mathrm{g} / \mathrm{L}_{2} \mathrm{O}$. The fluorescent 4-methylumbelliferone was measured with a fluorimeter (Perkin-Elmer Corp., Norwalk, CT, USA) at 455 nm.

\section{Statistical Analysis}

Values for all measurements were expressed as mean \pm standard error of the mean. Pairs of groups were compared using the Mann-Whitney $U$ test. Significance was set at a $p$ value of $\leq 0.05$.

\section{Results}

\section{HDMs and Fungal Components Induce Expression of} Chitinases in vitro

We investigated whether stimulation with chitin-containing pathogens, fungi, and mites via TLR could induce the expression of chitinase in a monocyte/macrophage cell line. Zymosan A of S. cerevisiae (fungi), a TLR-2 ligand, as well as whole-HDMs (Dermatophagoides pteronyssinus [Der.p.]) enhanced chitinase activity in the cellfree supernatant from the human monocyte cell line THP-1 shown in Figure 1a. We measured an 8-fold increase in chitinase activity after stimulation with zymosan A in relation to non-stimulated cells. The chitinase activity after stimulation with Der. p. was 50-fold higher than the control. These results were confirmed in bloodderived monocyte macrophages of human donors and in the mouse monocyte-macrophage cell line RAW 264.7 (data not shown). Zymosan A and HDMs also induced the expression of the chitotriosidase gene in THP-1 shown in Figure 1b. The expression of the AMCase gene was not detectable. Similarly, zymosan A and Der. p. induced the expression of the chitotriosidase gene in the mouse macrophage cell line RAW 264.7 and human blood-derived human monocyte-macrophages (data not shown). Stimulation with the bacterial cell wall component LPS, a ligand for TLR4, showed no chitinase induction (enzyme activity and gene expression).

\section{Inhibition of Dectin-1, TLR-2, or Mannose Receptor \\ Decreased Chitinase Activity in vitro}

Since TLR-2 and dectin-1, a transmembrane receptor that binds to yeast components, have been described to be involved in zymosan A and chitin recognition [10, $20,21]$, we investigated whether this is also true for the expression of chitinases in response to zymosan A. Therefore, we incubated THP-1 cells with blocking antibodies against TLR-2, dectin-1, or the mannose recep- 


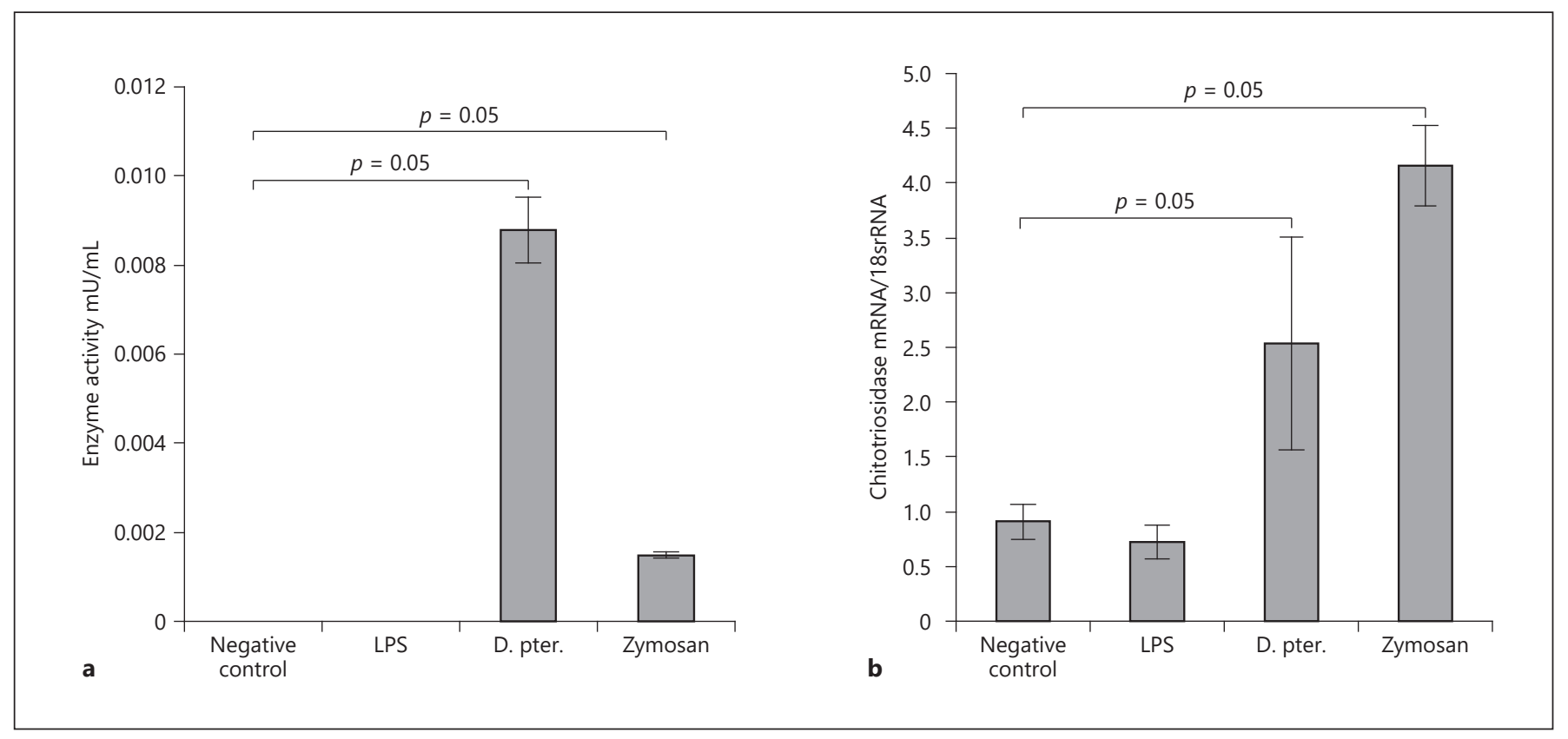

Fig. 1. Elevated chitinase activity after mite or fungi stimulation. Increased chitinase enzyme activity in supernatant (a) and increased chitotriosidase gene expression in THP-1 cells after stimulation with Dermatophagoides pteronyssinus or zymosan (b). No significant difference after LPS stimulation. Data are mean \pm SEM, $n=3$.

Table 1. White cell count and differentiation in BAL of nonallergic mice

\begin{tabular}{|c|c|c|c|c|c|c|}
\hline \multirow[t]{2}{*}{ Cell type } & \multicolumn{2}{|c|}{ Negative control $(n=3)$} & \multicolumn{2}{|c|}{ Zymosan $(n=3)$} & \multicolumn{2}{|c|}{ Zymosan and allosamidin $(n=7)$} \\
\hline & $10^{3}$ cells $/ \mathrm{mL}$ & $\%$ & $10^{3}$ cells $/ \mathrm{mL}$ & $\%$ & $10^{3}$ cells $/ \mathrm{mL}$ & $\%$ \\
\hline Lymphocytes & $0 \pm 0$ & 0 & $49 \pm 17$ & 6 & $18 \pm 6$ & 3 \\
\hline Neutrophiles & $2 \pm 1$ & 2 & $646 \pm 101$ & 84 & $460 \pm 113$ & 87 \\
\hline Eosinophiles & $0 \pm 0$ & 0 & $22 \pm 14$ & 3 & $9 \pm 4$ & 2 \\
\hline Macrophages & $40 \pm 23$ & 98 & $57 \pm 28$ & 7 & $44 \pm 15$ & 8 \\
\hline
\end{tabular}

BAL, bronchoalveolar lavage.

tor CD206, which recognizes a number of microbial proteoglycans, such as zymosan A. The expression of the chitinase gene was significantly inhibited after the addition of anti-dectin-1, anti-CD206, and to a lesser extent, with the anti-TLR-2 antibodies, as shown in Figure 2.

\section{Airway Stimulation of Nonallergic Mice with Chitin-}

Containing Components Induced Chitinase in BAL,

Bronchial Hyperreactivity, and Inflammation

We investigated whether the application of chitincontaining components to mice induced chitinase activity in the lung tissue and whether this was associated with bronchial hyperreactivity and inflammation. After the daily application of zymosan A via intratracheal application to female $\mathrm{BALB} / \mathrm{c}$ mice for 5 days, the activity of the chitinase enzyme in the BAL fluid was increased 2-fold in comparison to placebo-treated animals, as shown in Figure 3. The number of inflammatory cells in the BAL fluid and airway hyperreactivity increased as well, as shown in Figure 4. In comparison to the PBS control group, there was a significant increase in leucocytes harvested from BAL when zymosan A was administered. The BAL fluid demonstrated a higher number of lymphocytes, neutrophils, and eosinophils compared to the PBS control. This is shown in Table 1. 

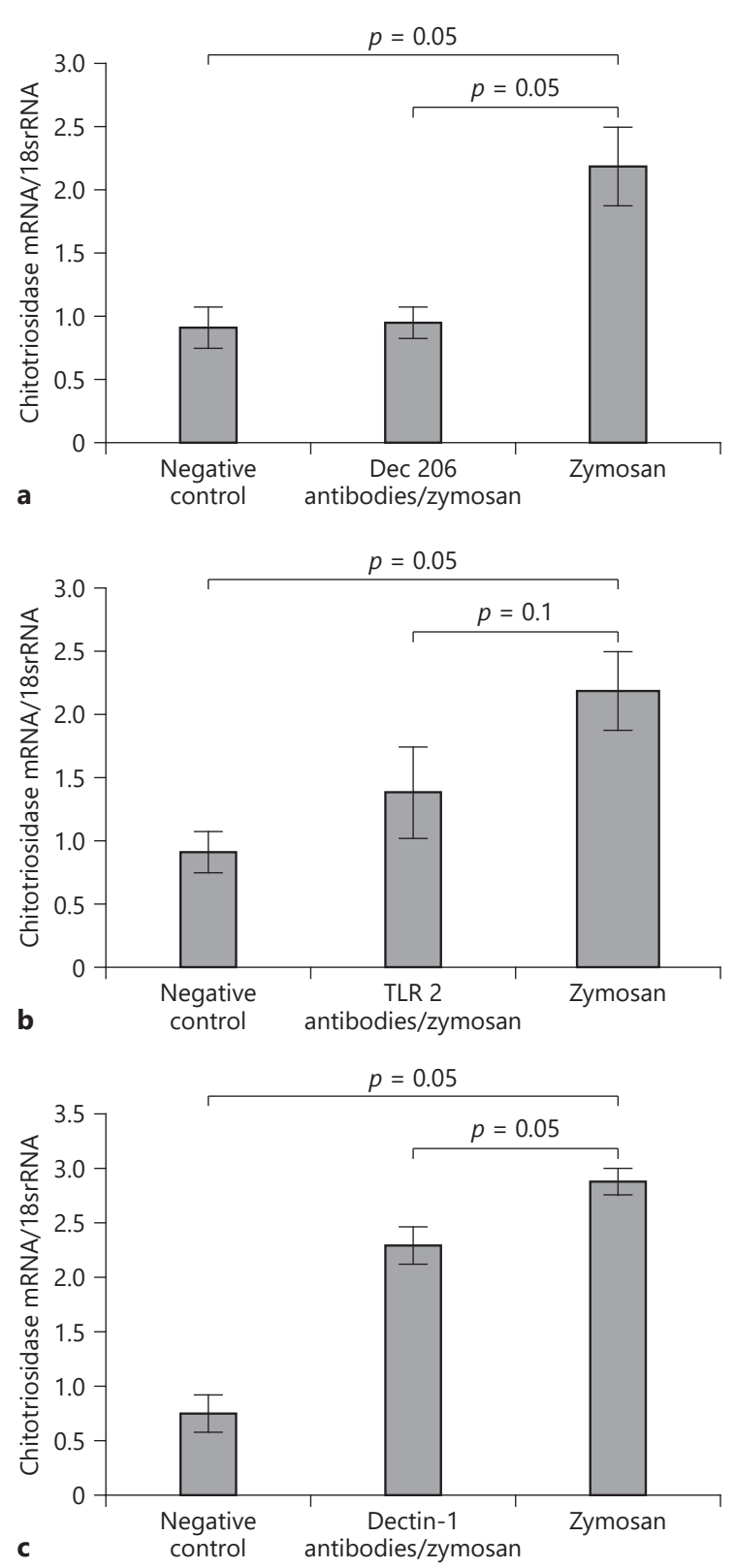

Fig. 2. Decreased gene expression of chitotriosidase mRNA was measured after stimulation of THP-1 cells with zymosan and inhibitory antibodies for Dec 206 (a), TLR-2 (b), or dectin-1 receptors (c). After addition of Dec 205, SIGN, or SIGN-related receptor antibodies, there was no inhibition of chitinase gene expression detected. Data are SEM, $n=3$. THP-1, human monocyte cell line.

\section{Amelioration of Airway Inflammation and}

Hyperreactivity after Chitinase Neutralization

To further investigate whether the chitinase pathway induced by zymosan A was crucial in the induction of

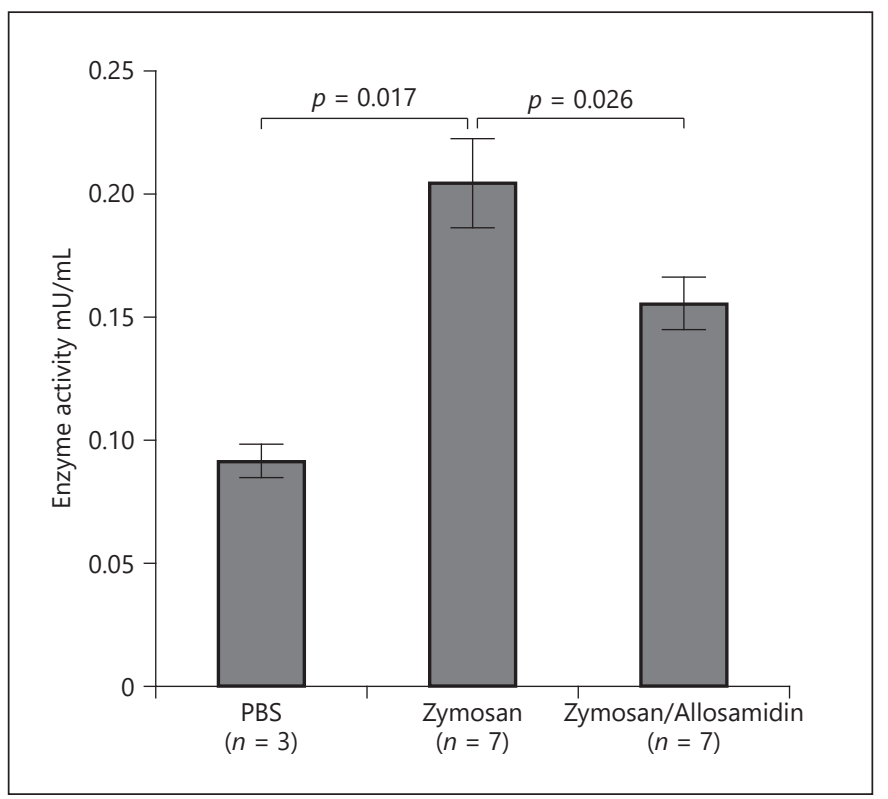

Fig. 3. BALB/c mice showed a significant increase of chitinase activity in BAL after daily intranasally stimulation with zymosan. After zymosan stimulation and daily intraperitoneal application of chitinase inhibitor allosamidin, we determined a decrease in enzyme activity. Data are mean \pm SEM. BAL, bronchoalveolar lavage.

nonallergic airway inflammation in mice, we blocked it with a daily intraperitoneal application of the chitinase inhibitor, allosamidin $4 \mathrm{~h}$ prior to the intranasal challenge of zymosan A. This chitinase inhibition resulted in the inhibition of chitinase enzyme levels (Fig. 3) and the cellular infiltration in the BAL fluid when compared to $\mathrm{Balb} / \mathrm{c}$ mice intranasally treated with zymosan $\mathrm{A}$, as shown in Figure 4.

In vivo lung functionality in response to $\mathrm{MCh}$ was improved in mice treated with zymosan A after chitinase inhibition, when compared with mice only treated with zymosan A, as shown in Figure 4. Furthermore, the percentage of lymphocytes and eosinophils was reduced in the BAL fluid after additional application of allosamidin to zymosan A, as shown in Table 1.

\section{Discussion/Conclusion}

We show here the first description of a model for an allergen-independent specific enhancement of airway inflammation and hyperreactivity by chitin. Our results show that chitin, a molecule contained in fungi and mites, is able to induce an increased expression of chitinase in murine and human macrophages, as well as in unsensi- 


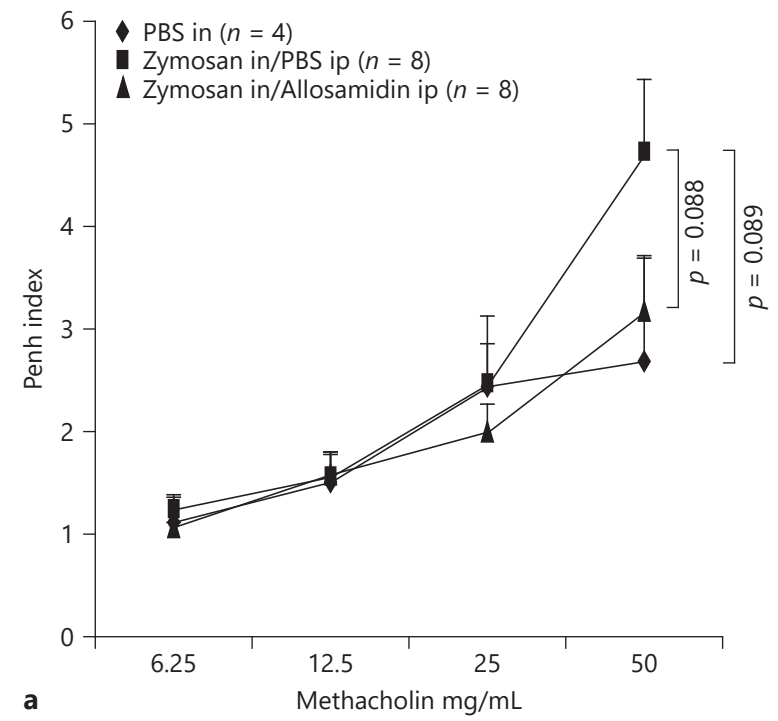

tized murine lung cells. Mice treated with the chitinaseinductor zymosan A showed elevated bronchial chitinase enzyme activity and displayed increased airway hyperreactivity and airway inflammation, whereas neutralization with the chitinase inhibitor allosamidin inhibited this. This suggests that chitin-containing pathogens may cause a direct and IgE-independent innate immune response resulting in the lung damage.

Our data suggest that ubiquitous environmental factors, such as mites or fungi can lead to airway inflammation and airway hyperreactivity independent of an allergic or IgE-mediated pathway. This may explain why exposure to these components can enhance the development of asthmatic symptoms without the requirement of specific sensitization $[9,22]$.

Our data might help to better understand the seemingly paradoxical observation in the Manchester Allergy and Asthma Study (MAAS), namely, that children in the allergen avoidance group with lower exposure to HDMs developed similar levels of specific sensitization, but significantly less asthma-like symptoms [23].

In the past, it was believed that mite exposure might be directly associated with the development of asthma. Exposure to fungi was proposed as one possible factor explaining this high asthma risk [8]. Our data now broaden this suggestion by showing that exposure to components that induce chitinase can induce airway inflammation and hyperreactivity. This conclusion aligns well with available epidemiological data: a worldwide study in 146 centers investigating climate and prevalence of asthma symptoms in children showed a close correlation of airway obstruction to increased indoor relative humidity and temperature [24], the former influencing the HDM infestation in homes [25]. Other factors influenced by the level of indoor relative humidity are home dampness and molds, both associated with the prevalence of asthma and bronchial hyperreactivity in several studies [25].

In a prospective cohort study, the German Multicenter

Fig. 4. Increased airway hyperresponsiveness and inflammation after intranasal fungal stimulation. Airway hyperresponsiveness (a) and airway inflammation (b) shown as cells/mL in the BAL fluid of nonallergic $\mathrm{BALB} / \mathrm{c}$ mice. Results after intranasal and intraperitoneal stimulation with PBS (a: $n=4, \mathbf{b}: n=3)$ as negative control, intranasal stimulation with zymosan with intraperitoneal PBS (a: $n=8$, b: $n=7$ ) or the chitinase inhibitor allosamidin (a: $n=8, \mathbf{b}: n=7)$. An increase of airway inflammation and hyperresponsiveness after chitin-containing zymosan and a downward trend after intraperitoneal chitinase inhibition could be shown. Data are mean \pm SEM. BAL, bronchoalveolar lavage. 
ciation between mammalian chitinase and bronchial asthma has been reported before [16].

Lee et al. [29] elegantly demonstrated in vitro that the chitinase-like molecule, Chi311, binds to the IL-13-receptor a2 and mediates biological responses, including the regulation of cellular apoptosis, oxidative tissue injury, and airway inflammation, thus linking this molecule with Th2-mediated allergic immune responses. Accordingly, serum levels of the chitinase-like protein YKL-40 showed significant correlations with the baseline lung function and were increased in children with a significant response in either the exercise challenge or the bronchodilator test [30]. Consequently, strategies to inhibit the induction of airway inflammation by blocking of chitinases would include attempts to obstruct upstream IL-13 production. Our data support the concept that chitinases induce host anti-parasite immune responses and that airway inflammation in asthma is enhanced by this pathway in a parasite-independent nonallergic way [31].

Environmental exposure to organisms such as fungi and mites directly induce chitinases and bronchial hyperresponsiveness, and we interpret it as a representation of an innate immune response to common molecular patterns associated with such organisms. Chitin has been shown to be a strong activator of the alternative complement pathway and thereby shapes the ensuing immune response upon inhalation [32]. Thus, we propose that the induction of chitinases contributes to asthma not only as a secondary enhancer of ongoing allergic airway inflammation but as a pivotal element in the initiation of bronchial hyperreactivity and asthma independent of an allergen-induced T2-type inflammation. Consequently, approaches to inhibiting the induction of airway inflammation and bronchial hyperreactivity would require effective measures for reducing the environmental exposure to organisms such as fungi and mites. Future studies have to prove whether this strategy will translate into a reduced risk for asthma development in children.

\section{Acknowledgement}

The authors would like to thank Christine Seib, Martin Krokowski, Anke Jaudszus, Kerstin Gerhold, and Christian Hahn of the Pediatric Pneumology and Immunology at Charité - Universtitätsmedizin, Berlin, Germany, along with Caroline Roduit of the Center for Allergy Research at Zurich University Children's Hospital for their assistance.

\section{Statement of Ethics}

The animal institutional Ethics Committee (Ethikkommission der Charité Universitätsmedizin Berlin) approved all the experimental procedures.

\section{Conflict of Interest Statement}

Dr. Christina Weber-Chrysochoou received honoraria for being part of an advisory board of Takeda and for a talk at CSL Bering. All other authors have no conflicts of interest to declare.

\section{Funding Sources}

Christina Weber-Chrysochoou, Susanne Loeliger, Remo Frei, and the materials for the cell stimulations were partly paid by Kühne Foundation, Schindellegi, Switzerland.

\section{Author Contributions}

C.W., R.L., and E.H. contributed to the design of the research. Y.D. and E.H. submitted the ethics application to the institute's committee on animal research. C.W., R.F., S.L., J.S., E.T., and Y.D. collected the data. C.W., Y.D., R.F., R.L., and E.H. contributed to the analysis of the data and to the writing of the manuscript.

\section{References}

Chitinase-Induced Nonallergic Asthma in Mice
1 Zahran HS, Bailey CM, Damon SA, Garbe PL, Breysse PN. Vital signs: asthma in children: United States, 2001-2016. MMWR Morb Mortal Wkly Rep. 2018 Feb 9;67(5):149-55.

2 Garden FL, Simpson JM, Marks GB, Investigators C. Atopy phenotypes in the Childhood Asthma Prevention Study (CAPS) cohort and the relationship with allergic disease: clinical mechanisms in allergic disease. Clin Exp Allergy. 2013 Jun;43(6):633-41.

3 Matricardi PM, Illi S, Grüber C, Keil T, Nickel R, Wahn U, et al. Wheezing in childhood: incidence, longitudinal patterns and factors predicting persistence. Eur Respir J. 2008 Sep; 32(3):585-92.
4 Lau S, Illi S, Sommerfeld C, Niggemann B, Bergmann R, von Mutius E, et al. Early exposure to house-dust mite and cat allergens and development of childhood asthma: a cohort study. Multicentre Allergy Study Group. Lancet. 2000 Oct 21;356(9239):1392-7.

5 Illi S, von Mutius E, Lau S, Niggemann B, Grüber C, Wahn U, et al. Perennial allergen sensitisation early in life and chronic asthma in children: a birth cohort study. Lancet. 2006 Aug 26;368(9537):763-70.

6 Morgan WJ, Crain EF, Gruchalla RS, O'Connor GT, Kattan M, Evans R 3rd, et al. Results of a home-based environmental intervention among urban children with asthma. N Engl J Med. 2004 Sep 9;351(11):1068-80. 
7 Langley SJ, Goldthorpe S, Craven M, Woodcock A, Custovic A. Relationship between exposure to domestic allergens and bronchial hyperresponsiveness in non-sensitised, atopic asthmatic subjects. Thorax. $2005 \mathrm{Jan} ; 60$ (1): $17-21$.

8 Halonen M, Stern DA, Wright AL, Taussig LM, Martinez FD. Alternaria as a major allergen for asthma in children raised in a desert environment. Am J Respir Crit Care Med. 1997 Apr;155(4):1356-61.

9 Rylander R, Norrhall M, Engdahl U, Tunsater A, Holt PG. Airways inflammation, atopy, and (1--> 3)-beta-D-glucan exposures in two schools. Am J Respir Crit Care Med. 1998 Nov;158(5 Pt 1):1685-7.

10 Da Silva CA, Chalouni C, Williams A, Hartl D, Lee CG, Elias JA. Chitin is a size-dependent regulator of macrophage TNF and IL-10 production. J Immunol. 2009 Mar 15;182(6): 3573-82.

11 Wills-Karp M, Karp CL. Chitin checking: novel insights into asthma. N Engl J Med. 2004 Sep 30;351(14):1455-7.

12 Zhu Z, Zheng T, Homer RJ, Kim YK, Chen NY, Cohn L, et al. Acidic mammalian chitinase in asthmatic Th2 inflammation and IL-13 pathway activation. Science. 2004 Jun 11; 304(5677):1678-82.

13 Zhao J, Zhu H, Wong CH, Leung KY, Wong WS. Increased lungkine and chitinase levels in allergic airway inflammation: a proteomics approach. Proteomics. 2005 Jul;5(11):2799807.

14 Bierbaum S, Nickel R, Koch A, Lau S, Deichmann KA, Wahn U, et al. Polymorphisms and haplotypes of acid mammalian chitinase are associated with bronchial asthma. Am J Respir Crit Care Med. 2005 Sep 22;172(12): 1505.

15 Possick JD, He S, Holm C, Gern JE, Roberg K, Anderson E, et al. Serum Chitinase Activity (CHTact) is elevated in children and adults with asthma. AJRCCM. 2008;177(Abstract Issue):A501.
16 Bierbaum S, Nickel R, Koch A, Lau S, Deichmann KA, Wahn U, et al. Polymorphisms and haplotypes of acid mammalian chitinase are associated with bronchial asthma. Am J Respir Crit Care Med. 2005 Dec 15;172(12): 1505-9.

17 Ober C, Tan Z, Sun Y, Possick JD, Pan L, Nicolae R, et al. Effect of variation in CHI3L1 on serum YKL-40 level, risk of asthma, and lung function. N Engl J Med. 2008 Apr 17; 358(16):1682-91.

18 Hamelmann E, Schwarze J, Takeda K, Oshiba A, Larsen GL, Irvin CG, et al. Noninvasive measurement of airway responsiveness in allergic mice using barometric plethysmography. Am J Respir Crit Care Med. 1997 Sep; 156(3 Pt 1):766-75.

19 Hollak CE, van Weely S, van Oers MH, Aerts JM. Marked elevation of plasma chitotriosidase activity. A novel hallmark of Gaucher disease. J Clin Invest. 1994 Mar;93(3):128892.

20 Underhill DM, Ozinsky A, Hajjar AM, Stevens A, Wilson CB, Bassetti M, et al. The Tolllike receptor 2 is recruited to macrophage phagosomes and discriminates between pathogens. Nature. 1999 Oct 21;401(6755): 811-5.

21 Gantner BN, Simmons RM, Canavera SJ, Akira S, Underhill DM. Collaborative induction of inflammatory responses by dectin-1 and toll-like receptor 2. J Exp Med. 2003 May 5; 197(9):1107-17.

22 Moghtaderi M, Ashraf MA, Teshnizi SH, Nabavizadeh H, Farjadian S, Fereidouni M. The level of allergens in dust samples collected from selected schools in Shiraz, Iran and its asthma-risk implications. Allergol Immunopathol. 2020 Jan-Feb;48(1):90-4.

23 Simpson A, Custovic A. Allergen avoidance in the primary prevention of asthma. Curr Opin Allergy Clin Immunol. 2004 Feb;4(1): 45-51.

24 Weiland SK, Hüsing A, Strachan DP, Rzehak $\mathrm{P}$, Pearce N. Climate and the prevalence of symptoms of asthma, allergic rhinitis, and atopic eczema in children. Occup Environ Med. 2004 Jul;61(7):609-15.
25 Peat JK, Dickerson J, Li J. Effects of damp and mould in the home on respiratory health: a review of the literature. Allergy. 1998 Feb; 53(2):120-8.

26 Koopman LP, van Strien RT, Kerkhof M, Wijga A, Smit HA, de Jongste JC, et al. Placebocontrolled trial of house dust mite-impermeable mattress covers: effect on symptoms in early childhood. Am J Respir Crit Care Med. 2002 Aug 1;166(3):307-13.

27 Custovic A, Simpson BM, Simpson A, Kissen P, Woodcock A. Effect of environmental manipulation in pregnancy and early life on respiratory symptoms and atopy during first year of life: a randomised trial. Lancet. 2001 Jul 21;358(9277):188-93.

28 Woodcock A, Lowe LA, Murray CS, Simpson BM, Pipis SD, Kissen P, et al. Early life environmental control: effect on symptoms, sensitization, and lung function at age 3 years. Am J Respir Crit Care Med. 2004 Aug 15; 170(4):433-9.

29 Lee CM, He CH, Nour AM, Zhou Y, Ma B, Park JW, et al. IL-13Ra2 uses TMEM219 in chitinase 3-like-1-induced signalling and effector responses. Nat Commun. 2016 Sep 15; $7: 12752$.

30 Knihtila H, Kotaniemi-Syrjanen A, Pelkonen AS, Savinko T, Malmberg LP, Makela MJ. Serum chitinase-like protein YKL-40 is linked to small airway function in children with asthmatic symptoms. Pediatr Allergy Immunol. 2019 Dec;30(8):803-9.

31 Elias JA, Homer RJ, Hamid Q, Lee CG. Chitinases and chitinase-like proteins in $\mathrm{T}(\mathrm{H}) 2$ inflammation and asthma. J Allergy Clin Immunol. 2005 Sep;116(3):497-500.

32 Roy RM, Paes HC, Nanjappa SG, Sorkness R, Gasper D, Sterkel A, et al. Complement component $3 \mathrm{C} 3$ and $\mathrm{C} 3 \mathrm{a}$ receptor are required in chitin-dependent allergic sensitization to Aspergillus fumigatus but dispensable in chitininduced innate allergic inflammation. mBio. 2013 Apr 2;4(2):e00162-13. 